\title{
Executive Summary Mississippi River and Tributaries Flowline Assessment
}

\begin{abstract}
By Jonathan A. Ashley and James W. Lewis MRG\&P Tech Note No. 7 • December 2018
\end{abstract}

MRG\&P

Mississippi River Geomorphology \& Potamology Program

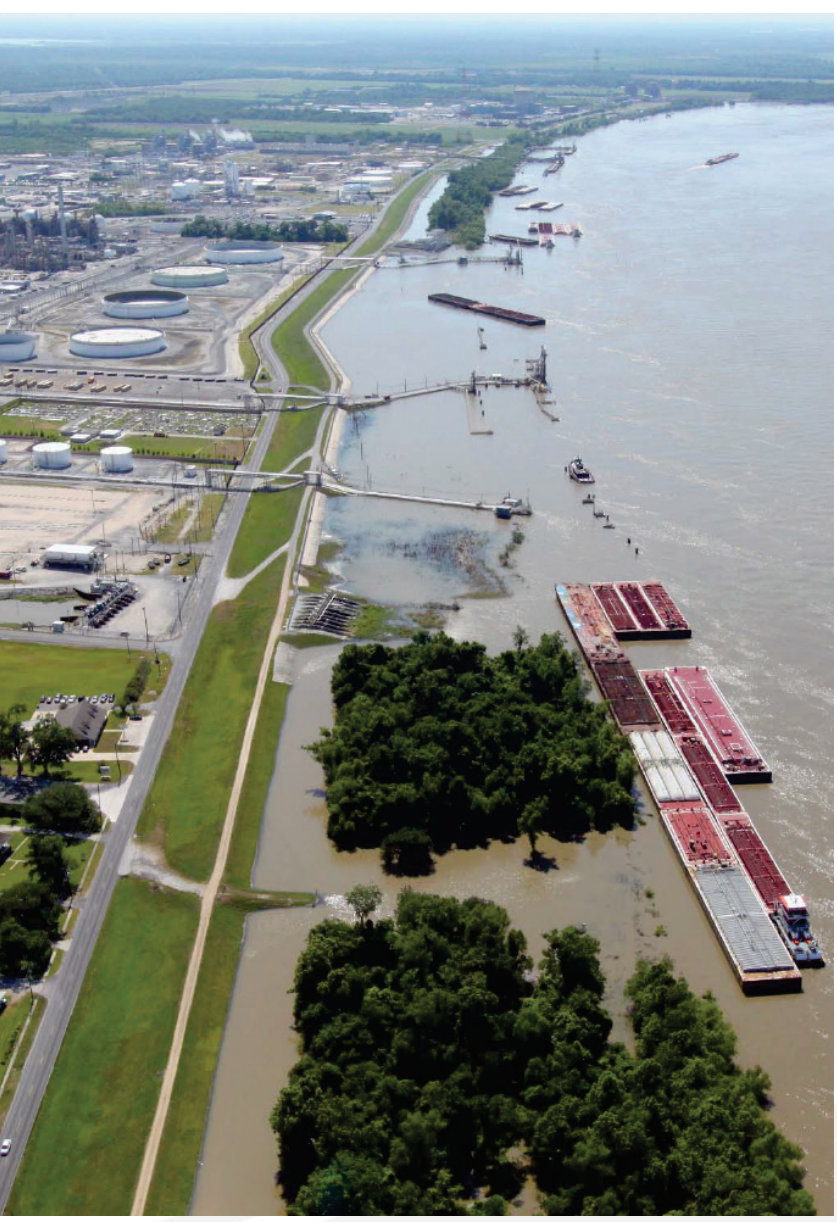




\section{MRG\&P \\ Mississippi River Geomorphology \& Potamology Program}

As a result of the 2011 Greater Mississippi River Basin Flood, the 2011 Mississippi River and Tributaries (MR\&T) Post Flood Report (USACE 2012) highlighted the need to conduct a flowline assessment for the MR\&T system. This assessment was to include data from the 2011 flood event and any physical, hydrologic, or hydraulic changes that had occurred in the river system to determine if a change in flowline or water control plans was warranted. The U.S. Army Corps of Engineers, Mississippi Valley Division (MVD) Commander at that time, MG John Peabody, also emphasized the need for an objective re-assessment of the flowline and meteorological conditions associated with the 1955 "Hypo Flood." Based upon this guidance, the flowline assessment was initiated in 2014 to address the issues outlined in the Post Flood Report along the main stem and to assess the Refined 1973 Flowline. This Technical Note is a summary of the Mississippi River and Tributaries Flowline Assessment Main Report (USACE 2018a). The assessment is intended to determine if the Hypo Flood associated with the currently authorized Refined 1973 Flowline (USACE 1978) is still sufficient; how the flowline has changed due to changes in river conditions; how the flowline changes utilizing updated technology and methods; and how the computed flowline compares to existing levee heights.

Key findings from the assessment include the following:

- The storm set (HYPO 58A) that is the basis for the Refined 1973 Flowline is still the governing hypothetical storm sequence, and a revision of meteorological events is not warranted.

- The flowline computed utilizing the 1955 methodology hydrologic inputs in the hydraulic model calibrated for present day river conditions indicated that channel capacity has changed, increasing the flowline less than $1 \mathrm{ft}$ at Cairo, IL, and from Vicksburg, MS, to Red River Landing, LA, and decreasing the flowline from Hickman, KY, to Lake Providence, LA.

- Improved methods, models, and reservoir operation assumptions for computing runoff resulted in higher peak flows with greater duration than were produced by the 1955 methodology employed for the Refined 1973 Flowline. Additional analyses of modeling parameters are needed to bracket modeling uncertainties.

- The flowline computed with new methodology hydrologic inputs in the hydraulic model calibrated for present day river conditions was higher than the 1973 Refined flowline everywhere except for the lowest reaches of the river.

- Backwater areas and floodways may not operate as designed due to the ever-evolving geomorphology and hydraulics of the river.The flowline calculated for the Atchafalaya, utilizing the completely new methodology, was lower than the presently authorized 2010 flowline.

- The flowline computed utilizing the 1955 methodology hydrologic inputs in the hydraulic model, calibrated for present day river conditions, exceeds existing levee elevations only at locations where authorized remaining work is required based on the Refined 1973 Flowline for existing conditions. Water surface elevations computed with the completely new methodology were higher than existing levee elevations at some locations in all three lower Districts. 


\section{MRG\&P \\ Mississippi River Geomorphology \& Potamology Program}

Based on the results of this technical assessment, it is determined that a new project design flowline is not warranted at the present time for the following reasons:

- Results utilizing the updated methodology do not change the risk-informed prioritization of authorized remaining work required to complete the MR\&T system.

- The meteorological conditions associated with the 1955 Hypo Flood still characterize the storm events that generate the Project Design Flood (PDF).

- Additional analyses are required to understand the sensitivity of hydrology model results to model parameters and varying assumptions regarding reservoir regulation. Results presented represent a single set of assumptions and input parameters.

Therefore, the following future activities are recommended:

- Complete the authorized remaining work based on the existing risk-informed prioritization.

- Advance hydrologic modeling capability and conduct required sensitivity analyses.

- Develop an operational HEC-RAS model of the Mississippi River valid over a range of flows for continued analysis.

- Continue geomorphic assessments of the river and incorporate data into the modeling framework as appropriate.

- Advance risk-based analysis techniques that consider all critical vulnerabilities and allow for a more comprehensive characterization of the flood hazard.

\section{ASSESSMENT PROCESS}

A flowline assessment evaluates flood magnitudes and associated routing effects to the river profile as a guide for levee grades and other flood control features along the Lower Mississippi River. To evaluate the existing flowline profile, a seven-step process was utilized considering current hydrologic and hydraulic conditions as well as any parameters that could impact the flowline over the next 50 years. These steps included the following.

Step 1: Develop Precipitation Amounts. The USACE in cooperation with the U.S. Weather Bureau (now the National Weather Service [NWS]) evaluated the hydrology for the MR\&T System in 1955. At that time, the NWS was asked to provide the largest storm series considered to have a reasonable chance of occurrence in the season when floods are likely to occur over the Mississippi River Basin. After investigating 35 different hypothetical storm series in the 1955 study (MRC 1955), the one that produced the greatest discharges from Cairo, IL, to the Gulf of Mexico (HYPO 58A) was selected as the PDF. HYPO 58A is a winter season storm series consisting of three storms. This included the January 1937 storm over all areas with rainfall increased by $10 \%$, followed 4 days later by the January 1950 storm over all areas above Cairo, IL, and 3 days later by the February 1938 storm rotated $20^{\circ}$ clockwise about Calvin, $\mathrm{OK}$, and transposed 90 miles northwest over all areas downstream from Cairo, IL. This potential flood produced the largest flows from the Ohio River Basin and for the Mississippi River at Arkansas City and latitude of Red River Landing. 


\section{MRG\&P \\ Mississippi River Geomorphology \& Potamology Program}

Extreme storm events have occurred since 1955 including the 1973 flood and the two storms that produced the 2011 flood. Following the 2011 flood, a storm meteorology review was completed and concluded that the maximized rainfall from the 2011 storms was much less than rainfall produced by HYPO 58A. Even if only the first two storms (January 1937 and January 1950, not including February 1938) were used from HYPO 58A, the combined rainfall from those two storms would exceed the maximized rainfall from the 2011 storm. For this assessment, the Project Delivery Team (PDT) also reviewed three other historical HYPO storms and a combination of the 1973 and 2011 floods (called HYPO 11-73) to analyze if these would produce a higher peak flood than the existing PDF. The results indicated that HYPO 58A still governed. The results of both analyses confirmed that a revision to the storm events associated with the current PDF was not warranted.

To account for precipitation totals under the 1955 methodology, the Mississippi River Basin was divided into seven regions to allow hydrologic hand computations to be completed at a manageable level. This included selectively applying storm sequences across the watershed. The individual storms comprising the HYPO storm were applied to selected sub-basins within the Mississippi River Basin, which allowed separate rainfall and runoff calculations for different sub-basins. This was done to maximize tributary effects while facilitating the myriad manual calculations needed to develop peak design discharges. As a result, this method resulted in discontinuous precipitation across adjacent sub-basin boundaries where different rainfall sequences were applied.

To evaluate precipitation amounts under this new analysis, individual historical storm event precipitation and temperature point data inputs were pieced together from different archives and interpolated to produce spatially continuous storm events over the entire Mississippi River Basin for the HYPO 58A storm. Rather than applying segmented rainfall amounts to differing sub-basins, a continuous simulation of precipitation moved across the entire watershed for this new methodology. By doing this, additional precipitation was accounted for by incorporating subbasins not included in the 1955 study (MRC 1955). Both the 1955 and current methods were evaluated for HYPO 58A to compare how much additional flow was produced under this new straight sequence method. In most instances, the straight sequence runs resulted in greater precipitation amounts and higher peak flows with greater duration than were produced by the previous methodology, further discussed in Step 3 below.

Step 2: Calculate Runoff. The Mississippi Valley Division and PDT collaborated with five NWS River Forecast Centers (RFCs) and the Tennessee Valley Authority (TVA) to generate inflows from historical precipitation records for the USACE hydraulic model to be used in the Flowline Assessment. This was the first re-evaluation of PDF inflows since the 1955 Flowline Study (MRC 1955). To determine the runoff, the current NWS operational hydrology model for determining daily river forecasts, the Community Hydrologic Prediction System-Flood Early Warning System (CHPS-FEWS) model was applied for the assessment. This model produced outputs for all modeled sub-areas and computation points within the NWS CHPS-FEWS configurations. This current, more refined hydrologic model included 7,066 sub-basins as compared to the 44 larger sub-basins evaluated in the 1955 study (MRC 1955). There were also improved calculations for rainfall and runoff through continuous soil moisture accounting, including the effects of snowmelt, and improved routing methods. After each RFC model run was completed, results were passed successively to downstream RFCs to use as inflows until simulations for the entire Mississippi River Basin were complete. Once a complete simulation 


\section{MRG\&P}

Mississippi River Geomorphology \& Potamology Program

from all CHPS-FEWS model segments was finished, the NWS Lower Mississippi River Forecast Center (LMRFC) exported the specific output locations needed back to USACE to run the Hydrologic Engineering Center River Analysis System (HEC-RAS) hydraulic model.

\section{Step 3: Calculate River Flow Derived from Runoff for Unregulated and Regulated} Conditions. For the 2016 analysis, runoff with and without reservoir effects were assessed by coordinating with five RFCs, the TVA, and ten USACE Districts. Improvements in routing from the last assessment included higher resolution through more and shorter river reaches and the use of unsteady hydrodynamic modeling. To maximize use of available data for comparisons, it was necessary to simulate both unregulated and regulated reservoir conditions to evaluate hydrologic model outputs against the previous results. The unregulated results provided a way to compare model results for 1955/1973 calculations and 2016 simulations with the only difference being basic hydrologic parameterization and calculations. Using the 2016 straight sequence methodology generally resulted in higher unregulated peak flows coming from the Upper Mississippi, listed in Table 1 . However, this represented only a small fraction of the total combined confluence flow of the Mississippi and Ohio Rivers.

Simulations applying the 1955 methodology hydrologic inputs in the 2016 hydraulic model produced peak regulated flows near or lower than values from the Refined 1973 Study for existing conditions, shown in Table 2. When the Yazoo backwater levees are raised to authorized elevations, the flows from Vicksburg south increase to greater than the Refined 1973 Study values. The complete 2016 methodology and model runs produced peak regulated flows and total volumes that were higher than values from the 1955/1973 study (USACE 1978) for both existing (listed in Table 2) and authorized conditions. There are several factors that could be identified as probable causes to the additional regulated flow. In addition to the added streamflow derived from the inflow generation method described above, at least three factors identified with reservoir regulation effects can be identified. One factor is the 1955 HYPO 58A-EN (EN represents the 1955 set of reservoirs that were existing or proposed to be constructed by 1970) results included reservoirs that were not constructed, which reduces the amount of storage available to reduce flood peaks routed downstream to Cairo, IL.

\begin{tabular}{|c|c|c|c||}
\hline \multicolumn{2}{||c|}{ Table 1. Comparison of unregulated peak flows for HYPO 58A (cubic feet per second). } \\
\hline \hline Location & $\begin{array}{c}\text { HYPO 58A } \\
\text { HYPO 58A } \\
\text { Refined 1973 Study }\end{array}$ & $\begin{array}{c}\text { 1955/1973 Precipitation and } \\
\text { Runoff Method } \\
\text { with 2016 Hydraulic Model }\end{array}$ & $\begin{array}{c}\text { HYPO 58A } \\
2016 \\
\text { Precipitation Method and } \\
\text { Models }\end{array}$ \\
\hline \hline Ohio @ Cairo, IL & $2,460,000$ & $2,392,678$ & $2,458,000$ \\
\hline $\begin{array}{c}\text { Miss/Ohio Confluence } \\
\text { (Combined) }\end{array}$ & $2,850,000$ & $2,785,000$ & $2,937,000$ \\
\hline New Madrid, MO & NA & $2,628,000$ & $2,751,000$ \\
\hline Caruthersville, MO & NA & $2,353,000$ & $2,391,000$ \\
\hline Osceola, AR & NA & $2,628,000$ & $2,915,000$ \\
\hline Memphis, TN & $2,770,000$ & $2,758,000$ & $2,956,000$ \\
\hline Helena, AR & $2,710,000$ & $2,684,000$ & $2,861,000$ \\
\hline Arkansas City, AR & $3,210,000$ & $3,065,000$ & $3,367,000$ \\
\hline
\end{tabular}




\section{MRG\&P}

Mississippi River Geomorphology \& Potamology Program

\begin{tabular}{|c|c|c|c|c|c|}
\hline Location & $\begin{array}{l}\text { HYPO 58A-EN } \\
\text { Refined } 1973 \\
\text { Study }\end{array}$ & $\begin{array}{c}\text { HYPO 58A } \\
1955 / 1973 \\
\text { Precipitation } \\
\text { and Runoff } \\
\text { Method with } \\
2016 \text { Hydraulic } \\
\text { Model Existing } \\
\text { Yazoo } \\
\text { Backwater } \\
\text { Levee Elevation }\end{array}$ & $\begin{array}{c}\text { HYPO 58A } \\
1955 / 1973 \\
\text { Precipitation and } \\
\text { Runoff Method } \\
\text { with } \\
2016 \text { Hydraulic } \\
\text { Model Authorized } \\
\text { Yazoo Backwater } \\
\text { Levee Elevation }\end{array}$ & $\begin{array}{c}\text { HYPO 58A-R } \\
2016 \\
\text { Precipitation } \\
\text { Method and } \\
\text { Models } \\
\text { Existing Yazoo } \\
\text { Backwater } \\
\text { Levee } \\
\text { Elevation }\end{array}$ & $\begin{array}{c}\text { HYPO 58A-R } \\
2016 \\
\text { Precipitation } \\
\text { Method and } \\
\text { Models } \\
\text { Authorized Yazoo } \\
\text { Backwater Levee } \\
\text { Elevation } \\
\end{array}$ \\
\hline Ohio @ Cairo, IL & $2,250,000$ & $2,255,000$ & $2,255,000$ & $2,326,000$ & $2,326,000$ \\
\hline $\begin{array}{l}\text { Miss/Ohio } \\
\text { Confluence } \\
\text { (Combined) }\end{array}$ & $2,360,000$ & $2,393,000$ & $2,393,000$ & $2,791,000$ & $2,791,000$ \\
\hline Memphis, TN & $2,410,000$ & $2,415,000$ & $2,415,000$ & $2,862,000$ & $2,862,000$ \\
\hline Helena, AR & $2,460,000$ & $2,445,000$ & $2,445,000$ & $2,787,000$ & $2,787,000$ \\
\hline Arkansas City, AR & $2,890,000$ & $2,874,000$ & $2,874,000$ & $3,263,000$ & $3,263,000$ \\
\hline Vicksburg, MS & $2,710,000$ & $2,678,000$ & $2,849,000$ & $3,076,000$ & $3,087,000$ \\
\hline Natchez, MS & $2,720,000$ & $2,694,000$ & $2,852,000$ & $3,072,000$ & $3,099,000$ \\
\hline $\begin{array}{l}\text { Red River } \\
\text { Landing }\end{array}$ & $2,100,000$ & $2,077,000$ & $2,226,000$ & $2,449,000$ & $2,475,000$ \\
\hline Baton Rouge, LA & $1,500,000$ & $1,501,000$ & $1,616,000$ & $1,838,000$ & $1,869,000$ \\
\hline Carrollton, LA & $1,250,000$ & $1,250,000$ & $1,360,000$ & $1,581,000$ & $1,613,000$ \\
\hline
\end{tabular}

Second, operation of reservoir projects to achieve maximum reductions at Cairo, IL, as estimated for the 1955 HYPO 58A-EN results would be difficult in reality during regular flood operations. The 1955 study (MRC 1955) assumed a defined percentage reduction from the EN set of reservoirs assuming full use of reservoir storage. In actual operation, it is not possible to know the full future storage requirements for a major flood like HYPO 58A beforehand. For the 2016 analysis, detailed reservoir routing was accomplished by each District using current water management plans and reservoir simulation modeling to determine reservoir release decisions and actual storage available.

A third effect of this new and improved modeling methodology is accounting for volume and timing of the regulated flows. In addition to comparing peak discharges and a visual comparison of hydrograph plots, hydrograph shape was assessed using volume and mean discharge over 3-, 15-, and 30-day periods. Results from the current assessment yielded higher 1-day peaks as well as larger volumes than obtained from the 1955/1973 analysis. This means a larger volume of flow actually passed through the system for the 2016 simulations than indicated from the 1955/1973 study (USACE 1978). This may have limited the ability of reservoirs to reduce releases since they had to account for additional volumes of water. The timing of the peak values were also different. The 2016 peaks occurred approximately 6 days earlier than indicated in the 1955/1973 study (USACE 1978).

Step 4: Calculate Water Surface Profiles. Calibrated to the 2011 Mississippi River flood, unsteady flow hydraulic models of the MR\&T domain (Chester, IL / Smithland, KY, to Venice, LA) were used to assess the flowline. Using one-dimensional (1D) and two-dimensional (2D) elements of the HEC-RAS model, water surface elevations were simulated for the historical and 


\section{MRG\&P \\ Mississippi River Geomorphology \& Potamology Program}

new hypothetical events. For the historic runs, hydrologic inflows were the same as the Refined 1973 Flowline Study (USACE 1978), which were also the same as in the 1955 study (MRC 1955). For the new hypothetical HEC-RAS simulations, all of the required upstream inflow boundary conditions were pulled from the NWS hydrologic model, which produced higher regulated flows compared to the 1955 hydrology.

Changes between the previously published stages in the Refined 1973 Flowline Study (USACE 1978) and the results of the historic simulations of this assessment highlight differences between the modeling methodology, changes in the channel geometry over time, and changes in channel roughness. For high flows, the river has experienced dynamic equilibrium or slightly decreasing stages between Hickman and Arkansas City. From Arkansas City to Red River Landing, the river has experienced increasing stages for high flows according to geomorphic analysis (Biedenharn et al. 2017). Peak water surfaces from near Vicksburg and going downstream to around Red River Landing agree with the geomorphic observation of increasing stage trends as the simulated water surfaces are higher for the current assessment than the Refined 1973 Flowline Study (USACE 1978) for those reaches of the river.

Table 3 lists a comparison of peak stages produced from the hydraulic modeling. Many of the water surface elevations are approximately 1 to $6 \mathrm{ft}$ higher in the 58A-R (2016 58A Regulated) Authorized Yazoo simulation than the Refined 1973 Flowline Study (USACE 1978) water surfaces, converted to the North American Vertical Datum (NAVD88). Analysis was performed for both the existing and authorized Yazoo Backwater Area levee elevations. The Yazoo Backwater levee is the only backwater area not at its Refined 1973 Flowline authorized grade, currently at $107.0 \mathrm{ft}$ rather than the authorized $112.8 \mathrm{ft}$ NAVD88. For equal comparison, none of the data sets compared in Table 3 include loop effect or channel degradation impacts. The water surface results for the most downstream 50 miles of the river are lower in the current assessment than the Refined 1973 Flowline Study (USACE 1978) due to differences in downstream boundary condition assumptions. The rating curve boundary condition produced differences from the Refined 1973 Flowline Study (USACE 1978) assumptions. The amount of water that is flowing out of the river through natural and man-made diversions is also much higher now in the downstream 40 miles of the Mississippi River than it was in the 1970s.

A hydraulic assessment was also done for the Atchafalaya River, incorporating the updated features of unsteady 1D and 2D HEC-RAS modeling to calculate the water surfaces during the hypothetical PDF events. The upstream boundary conditions for the Atchafalaya River included Old River outflow channel flows, Red River flows, and Morganza Floodway flows from the Mississippi River HEC-RAS model. In general, the calculated Atchafalaya River water surfaces were lower than the currently authorized 2010 flowline. This is understandable due to a number of modeling differences, such as unsteady 2D hydraulic calculations compared to steady-state 1D calculations used in the 2010 study (USACE 2010), a lower downstream boundary water surface than the 2010 study, and less flow than the 2010 study. In addition to modeling differences, channel surveys in recent years have consistently shown wide-spread scouring, or channel lowering, in the Upper Atchafalaya River. In the Lower Atchafalaya Basin there has been a long trend of accretion occurring in the river channel and in the floodplain areas. This filling has caused the stage-flow relationships to increase for all flow regimes. 


\section{MRG\&P}

Mississippi River Geomorphology \& Potamology Program

\begin{tabular}{|c|c|c|c|c|c|}
\hline Location & $\begin{array}{c}\text { HYPO 58A- } \\
\text { EN* } \\
\text { Refined } \\
1973 \text { Study }\end{array}$ & $\begin{array}{c}\text { HYPO 58A } \\
1955 / 1973 \\
\text { Precipitation } \\
\text { and Runoff } \\
\text { Method with } \\
2016 \text { Hydraulic } \\
\text { Model Existing } \\
\text { Yazoo } \\
\text { Backwater } \\
\text { Levee Elevation }\end{array}$ & $\begin{array}{c}\text { HYPO 58A } \\
\text { 1955/1973 } \\
\text { Precipitation } \\
\text { and Runoff } \\
\text { Method with } \\
2016 \text { Hydraulic } \\
\text { Model } \\
\text { Authorized } \\
\text { Yazoo } \\
\text { Backwater } \\
\text { Levee Elevation }\end{array}$ & $\begin{array}{c}\text { HYPO 58A-R } \\
2016 \\
\text { Precipitation } \\
\text { Method and } \\
\text { Models } \\
\text { Existing Yazoo } \\
\text { Backwater } \\
\text { Levee Elevation }\end{array}$ & $\begin{array}{l}\text { HYPO 58A-R } \\
2016 \\
\text { Precipitation } \\
\text { Method and } \\
\text { Models } \\
\text { Authorized } \\
\text { Yazoo } \\
\text { Backwater } \\
\text { Levee Elevation }\end{array}$ \\
\hline $\begin{array}{l}\text { Mississippi at Ohio } \\
\text { River }\end{array}$ & 331.7 & 332.0 & 332.0 & 334.3 & 334.3 \\
\hline Hickman & 320.7 & 318.6 & 318.6 & 321.4 & 321.4 \\
\hline Memphis & 237.2 & 235.8 & 235.8 & 241.4 & 241.4 \\
\hline Helena & 202.9 & 201.9 & 201.9 & 206.0 & 206.0 \\
\hline Arkansas City & 155.5 & 154.8 & 154.8 & 158.9 & 159.0 \\
\hline Greenville & 145.2 & 144.0 & 144.2 & 148.0 & 148.2 \\
\hline Lake Providence & 129.4 & 127.5 & 128.1 & 131.7 & 132.0 \\
\hline Vicksburg & 106.9 & 107.0 & 108.8 & 111.3 & 111.7 \\
\hline Natchez & 82.7 & 83.6 & 85.2 & 88.0 & 88.4 \\
\hline Red River Landing & 63.5 & 63.5 & 65.5 & 69.3 & 69.8 \\
\hline Baton Rouge & 45.7 & 444.4 & 47.1 & 52.1 & 52.8 \\
\hline Carrollton & 19.6 & 16.8 & 18.6 & 22.3 & 22.8 \\
\hline Venice & 8.1 & 3.8 & 3.9 & 4.1 & 4.2 \\
\hline
\end{tabular}

*From the Refined 1973 Flowline Study (USACE 1978), shown without loop, sedimentation, or freeboard effects.

Step 5: Develop Estimates for Future Sedimentation, Climate Change, Loop Effect, Sea Level Rise, and Subsidence. Additional evaluations were completed to assess the impacts of sedimentation, climate change, loop effect, sea level rise, and subsidence. Sedimentation in the Mississippi River over the next 50 years is expected to cause 2016 peak water surface elevations to increase by up to $2.5 \mathrm{ft}$ between Head of Passes (River Mile [RM] 0.0) and Helena (RM 663). During the same period, peak water-surface elevations between Helena and Cairo (RM 953) are expected to decrease. The Atchafalaya River sediment model showed that the PDF event itself will scour channel bed elevations by a large amount during the rising flows up to the peak, especially near Morgan City where a large amount of floodplain flow rejoins the river. Over the next 50 years, the sediment model results project trends of aggradation, or higher water surfaces, into the future for the Lower Atchafalaya River. Although the Upper Atchafalaya River has clearly exhibited large amounts of scour in recent decades, the sediment model projects a dynamic equilibrium to slightly increasing trend in water surfaces going forward. Future water surfaces in the upper reach could be lower than model projections due to channel widening, a process which should be included in future sediment modeling efforts of the Atchafalaya River.

A review of climate trends indicated conflicting results showing both an upward and downward trend for the same basins. The Mississippi River 2011 Post Flood Assessment concludes that a 


\section{MRG\&P \\ Mississippi River Geomorphology \& Potamology Program}

projected increase in maximum dew point temperature would require a revision to the rainfall used for the PDF, but current precipitation values are valid for the climate trend data available. As such, the current meteorological and hydrological assumptions for the MR\&T PDF are considered adequate for the present climate.

Loop effect, also known as hysteresis, is a phenomenon of river hydraulics where a falling river will pass a given discharge at a higher stage than a rising river. Analysis for loop effect compared observed discharge measurements, taken at specific stages, with HEC-RAS simulated results for recent high flow events. The analysis revealed that the HEC-RAS model that was used captured much of the loop effect but not its entirety. To fully account for the loop effect, an estimate of 1 to $2 \mathrm{ft}$ was added from Hickman to Baton Rouge for comparison to the currently authorized PDF and is further explained in the Main Report..

For this analysis, future sea level rise was incorporated into the downstream boundary conditions of the HEC-RAS model to estimate its impact for the next 50 years. Sea level rise simulations show that sea level rise could cause an increase of as much as $1.4 \mathrm{ft}$ from the Gulf of Mexico to above New Orleans (USACE 2018b). Although there is subsidence occurring in the lower reach of the Mississippi River, the future conditions calculations were not adjusted for subsidence. This assumption is applicable since the flowline was computed relative to the terrestrial datum NAVD88 and is further explained in the Main Report.

Step 6: Develop Flowline Comparisons to Levees. The flowline computed utilizing the 1955 hydrologic inputs in the 2016 hydraulic model exceeds the existing levee elevations only at locations where authorized remaining work is required based on the Refined 1973 Flowline for existing conditions. To relate the 2016 58A-R flows to current levee heights, certain assumptions were required. For the first run, the Old River Control Complex and all four floodways were operated at design capacity using existing backwater levee conditions. When flows exceeded design capacity for the structures, flows were routed downstream. Additionally, the mainline levees were artificially raised in the model to avoid volume loss through overtopping and pass flow downstream. This allowed the model to calculate water-surface elevations, which would be used to determine a rough order of magnitude of the miles of levee that would be impacted by the 2016 58A-R as compared to the currently authorized Refined 1973 PDF levee heights. The 58AR Authorized Yazoo and 58A-R Existing Yazoo computed values were compared with the Refined 1973 Flowline computed values for similar comparison not including the effects of loop, sedimentation, or freeboard.

Under the 2016 58A-R flows with assumptions mentioned above, the results showed that the computed water surfaces were higher than existing levee elevations in some locations in all three lower Districts. Three of the four floodways would be used (West Atchafalaya not activated), and only one of four backwater areas (the Yazoo) would be substantially activated. The model showed that under this scenario, additional flow would remain throughout the system.

A second model run was undertaken similar to above but using the authorized Yazoo backwater levee conditions of $112.8 \mathrm{ft}$. The other three backwater area levee elevations are at or above grade. Under these assumptions, this run resulted in slightly higher stages in all three lower Districts. This model change had no effect on stages above Memphis, TN. Three of the four floodways (West 


\section{MRG\&P}

Mississippi River Geomorphology \& Potamology Program

Atchafalaya not activated) would activate with this model run. The Yazoo backwater area was only minimally activated with the levee at the authorized elevation.

Step 7: Perform Quality Control Review. All of the above studies and model runs have been thoroughly reviewed, undergoing District Quality Control, Agency Technical Review, and Independent External Peer Review in accordance with the latest Civil Works Review Policy guidance. Comments from these reviews are included as an appendix to the Main Report.

CONCLUSION: Following the 2011 Greater Mississippi Basin flood, MVD was directed to develop a comprehensive approach for managing and improving the MR\&T system. An assessment of remaining authorized work required for project completion was conducted and formed the basis for an MR\&T Master Plan. The MR\&T Master Plan was also to be informed by an assessment of the PDF to ensure that the most up to date meteorological science was applied. This report documents the results of the PDF assessment. Results from the assessment do not change the risk-informed schedule for remaining work required for project completion contained in the MR\&T Strategic Investment Plan. Therefore, a key conclusion from the assessment is that the activities to complete the authorized remaining work should continue as presently scheduled.

A key finding from the assessment is that the meteorological conditions associated with the 1955 Hypo Flood still characterize the storm event that generates the PDF. A suite of models was applied to calculate runoff and to simulate the resulting PDF water surface elevation. The results of the modeling are dependent on numerous model input parameters and assumptions. The results presented in the report represent a single set of assumptions and input parameters and do not include an assessment of model sensitivity to model parameters or to varying assumptions regarding reservoir regulation. While the results from this assessment provide a baseline of understanding, future activities will advance the modeling framework and analysis required for a comprehensive approach to operating and maintaining the MR\&T project into the future.

The assessment also confirmed that the MR\&T Project does not always operate as the system intended due to the ever evolving geomorphology and hydraulics of the river. Efficient management of the system requires the most up to date and technically competent data and analyses and the following future activities are therefore recommended:

- Advance hydrology modeling capability. Planning and understanding risk for the MR\&T requires efficient and accurate hydrology simulations. Runoff for the assessment was computed by the National Weather Service (NWS), which applied its operational hydrology model for determining daily river forecasts, the Community Hydrologic Prediction System Flood Early Warning System (CHPS-FEWS). Time constraints on the NWS and no in house capability for the Corps limited the team's ability to address sensitivity to model parameters as well as sensitivity to climate change and different rainfall depths, durations, and intensities. Alternative reservoir regulation assumptions could also not be evaluated. Therefore, a hydrology capability should be developed for running the CHPS-FEWS model as well as to investigate alternative hydrology modeling approaches to provide efficient and accurate hydrology results. Efficient hydrology simulation will allow for extensive analysis of hydrology model parameters and inputs, understanding effects of climate change, and simulations for optimizing ways to regulate key projects in the basin. 


\section{MRG\&P \\ Mississippi River Geomorphology \& Potamology Program}

- Develop operational HEC-RAS model of the Mississippi River. An unsteady HEC-RAS model of the MR\&T domain was developed for the assessment. The model was calibrated for high flows only. Efficient management of the MR\&T requires a model that is kept up to date and is valid over a range of flows such that it can be run operationally. A process, tools, and techniques to obtain, store, and ingest required data for simulation should be developed. The model should be calibrated and verified for low flow events to ensure accurate simulation over a range of flows. The model can then be run operationally and compared to data on a recurring basis. This process will allow for continuous evaluation and update of the model to ensure its accuracy as well as allow for efficient future application as necessary.

- Continue geomorphic assessments of the river. The dominant morphological processes that shape the Mississippi River channel operate over a very large range of spatial and temporal scales. There are many factors, both natural and man-induced, that can contribute to these processes. The effects of large flood events, changing sediment loads and characteristics, channel maintenance activities, dredging practices, diversions (natural and man-made), and relative sea level rise are just a few such factors. Morphologic changes have important implications related to stage-discharge relationships and operating various flood control features of the MR\&T. Geomorphic and sedimentation studies on the Mississippi River should continue to be conducted to determine trends and river processes for better long-term management of the river.

- Advance risk based analysis techniques. A comprehensive approach for managing and improving the MR\&T project requires risk-informed decision making. Risk-informed decision making requires tools and techniques that consider all the critical vulnerabilities, are done probabilistically, and appropriately incorporate uncertainty. Studies should be conducted and tools developed to support system-wide, risk-informed river management. State-of-the-art approaches to properly characterize the probability of hazards and consider appropriate non-exceedance confidence limits should be evaluated and incorporated as necessary into the planning process.

- Utilize the results of this assessment and the additional recommended activities above for monitoring, managing and improving the MR\&T system to ensure safe passage of future floods.

\section{REFERENCES}

Biedenharn, D. S., M. A. Allison, C. D. Little, C. R. Thorne, and C. C. Watson. 2017. Large-scale Geomorphic Change in the Mississippi River from St. Louis, MO to Donaldsonville, LA, as Revealed by Specific Gage Records. MRG\&P Report No. 10. Vicksburg, MS: U.S. Army Engineer Research and Development Center. https://erdc-library.erdc.dren.mil/xmlui/handle/11681/22744.

Mississippi River Commission (MRC). 1955. Memorandum Report No. 1, Appendix J-- Mississippi River Basin: Meteorological Study. Vicksburg, MS: Mississippi River Commission, U.S. Army Corps of Engineers.

U.S. Army Corps of Engineers (USACE). 1978. Refined 1973 MR\&T Project Flood Flowline. Vicksburg, MS: U.S. Army Engineer District, Vicksburg.

USACE. 2010. Mississippi River and Tributaries, Atchafalaya Basin, Louisiana. 2010 Refined Project Flood Flow Line, Hydraulic Design, Revised February 2011. 


\section{MRG\&P \\ Mississippi River Geomorphology \& Potamology Program}

USACE. 2012. Mississippi River and Tributaries System, 2011 Post-Flood Report. Vicksburg, MS: U.S. Army Corps of Engineers, Mississippi Valley Division. http://www.mvd.usace.army.mil/Portals/52/docs/ regional flood risk management/Docs/MRT PostFloodReport (Main\%20Report).pdf

USACE. 2018a. Mississippi River and Tributaries Flowline Assessment Main Report. MRG\&P Report No. 24; Volume 1. Vicksburg, MS: U.S. Army Engineer Research and Development Center.

USACE. 2018b. Mississippi River and Tributaries Flowline Assessment Hydraulics Report. MRG\&P Report No. 24; Volume 3. Vicksburg, MS: U.S. Army Engineer Research and Development Center. 